\title{
ERRATUM
}

\section{Les représentations identitaires dans le discours \\ normatif des chroniqueurs de langage \\ canadiens-français depuis le milieu du XIX siècle}

\author{
WIM REMYSEN
}

DOI:Io.IoI7/So9592695Iroo0536 Published online by Cambridge University Press: I 3 December 20 I I

In 'Les représentations identitaires dans le discours normatif des chroniqueurs de langage canadiens-français depuis le milieu du XIX siècle' an element in 'Tableau I. Mouvements identitaires des Canadiens français (depuis I680)' contained a misprint. The date should be I 608 not I 680 .

\section{Reference}

Remysen, W. (20II). Les représentations identitaires dans le discours normatif des chroniqueurs de langage canadiens-français depuis le milieu du XIX ${ }^{\mathrm{e}}$ siècle. Journal of French Language Studies. DOI:I0. Io I7/So9592695 I I000536 